\title{
European Union experience in digitizing historical and cultural heritage: ways of implementation in Ukraine
}

\author{
M. O. Shevchenko \\ Kharkiv State Academy of Culture, Kharkiv, Ukraine \\ Corresponding author. E-mail: shmaryna.94@gmail.com
}

Paper received 21.02.20; Accepted for publication 18.03.20.

\section{https://doi.org/10.31174/SEND-HS2020-230VIII38-17}

\begin{abstract}
The relevance of this study is due to the need for the cultural integration of Ukraine into a single information and cultural space of Europe, which requires the effective digitization of the historical and cultural heritage. The aim of this article is to study the experience of EU Member States and to identify the directions for an efficient digitization process in Ukraine. Research methodology. The article reviews regulatory documents and acts of the European Union and Ukraine, examines scientific publications on the subject. In the process of the research, a comparative approach and the general scientific methods such as analysis, synthesis, generalization were used. Results. The experience of the European Union in organizing successful implementation of historical and cultural heritage integration resource digitization and formation projects are studied. Priority directions for effective digitization in Ukraine under European integration are identified. The novelty of the study is to integrate the European experience and best practices of the EU Member States into digitization of Ukraine's historical and cultural heritage. The practical significance. The main findings of the study can be used to develop a national strategy for digitization and distribution of responsibilities between subjects. Conclusion. Digitization of the historical and cultural heritage and formation of digital collections is one of the ways of successful implementation of Ukraine's cultural integration with the European Union. This requires the following measures: development and implementation of a national strategy for digitizing the historical and cultural heritage, which should cover the integration of Ukraine and the EU in the cultural space; and establishment of an appropriate coordinating organization and a sustainable financing system.
\end{abstract}

Keywords: European integration, Europe's single digital space, cultural integration, cultural policy, historical and cultural heritage, digitization, national digitization strategy.

Introduction. At its pivot point, Ukraine has given priority to the European integration vector of further development. Cultural cooperation with the European Union (EU) is one of the important areas of European integration. Effective cultural integration requires coordinated work between Ukraine's public authorities, social institutions, private organizations and the reform and development of sound cultural policy. An important area of cultural policy is the preservation of cultural heritage. In recent decades, the use of digital technologies has provided new opportunities for the preservation, dissemination and promotion of cultural heritage. The digitization of the historical and cultural heritage and the formation of relevant digital collections has become a trend in the contemporary cultural policy of the EU Member States.

The relevance of this problem for Ukraine is explained by the current poor cultural integration into the single information and cultural space of Europe. In the context of European integration, greater openness to intercultural dialogue is important for Ukraine. First of all, it concerns the presentation of the achievements of its unique culture in the single digital space of Europe.

This issue requires thorough scientific research in order to make optimal decisions at the state level for further effective practical implementation. Its solution will facilitate several processes at once: 1) increasing the level and rate of digitization of Ukraine's historical and cultural heritage, forming and expanding its own information space, providing users with access to the best samples of documentary heritage; 2) creating the prerequisites for integration into the Single Information Space of Europe and presentation of its own unique culture in the EU.

Research publications. The source of scientific investigation was the study of scientific works on the identified issues, the review of EU and Ukrainian regulatory documents and regulations, the study of the experience of EU Member States in digitizing cultural heritage.
Ukrainian scientists devote their research to a thorough analysis of regulatory documents, national programs, and digitization projects implemented in the EU. In particular, O. M. Rybachok in his Ph.D. thesis "International Integrated Digital Resources of the Documentary Heritage of Archives, Libraries, Museums: Stages of Creation, Development Strategies (the 80s of the 20th - 10th of the 21st centuries)" [22] pays heed to the study national strategies and projects for the digitization and creation of national resources for the historical and cultural heritage of European countries, analyzes the EU's experience in forming integrated resources for the historical and cultural heritage.

EU regulatory documents, which provisions regulate the protection and preservation of cultural heritage, and the European experience of creating integrated digital resources of cultural heritage are studied in scientific publications by O. I. Melnychuk [15], L. F. Prykhodko [20]. V. V. Dobrovolska [7], I. O. Kostyria [13], S. P. Kuchyn [14], M. I. Shevchenko [23] also consider the current state of Ukrainian cultural policy and its reformation in the context of European integration in their works.

However, despite the considerable amount of thorough scientific work, the problem of digitization of the historical and cultural heritage and integration into the digital resources of the EU cultural heritage has not yet found sufficient scientific solution and effective implementation in Ukraine.

The aim of this article is to study the experience of the EU Member States, to identify priority tasks and ways to solve them for effective digitization of the historical and cultural heritage in Ukraine in the context of integration into the European digital space.

Materials and methods. This study was based on the review of regulatory documents and legal acts; the study of scientific publications devoted to a multidimensional study of this problem. In the course of the research, a comparative approach and the following general scientific methods 
were used: analysis, synthesis, generalization.

Results and discussion. An important thing in today's European integration processes of Ukraine is to study and learn from the experience of the leading EU countries, including in cultural policy. In the 90 s of the 20 century at the beginning of the 21 century, the development of the information society, the spread of information and communication technologies, the digitization of all spheres of human life led to rethinking of the place and role of culture. The EU sees cultural heritage as a catalyst for the Union's economic, social, and political development and growth. EU cultural policy is characterized by the presence of a priority direction - preservation of cultural heritage for future generations, its promotion and dissemination. Therefore, the European Commission and EU Member States systematically review and amend cultural policy, update existing and develop new cultural heritage preservation programs, and implement historical and cultural heritage digitization projects. One of the major achievements of the European Union can be considered the launch and further development of Europeana. Today, Europeana [8] is a digital platform that represents and provides access to Europe's cultural heritage, based on the provisions of pan-European cooperation between EU Member States' institutions and the European Commission, copyright requirements, open access requirements. As of early January 2020, according to Europeana collections [8], access was granted to $58,493,795$ million objects, grouped into 5 categories: image - 33,878,043 (approximately 58.00\%); text — 22,669,817 (38.81\%); video — 1,139,662 (1.95\%); sound - 696,623 (1.19\%); and 3D - 23,760 (0.04\%).

The consistency of the research and the soundness of the EU's approach to preservation and digitization is evidenced by the large number of documents adopted in the EU and implemented by EU Member States. For example, one of the first to be called is the Maastricht Treaty (establishment of the European Union, which entered into force in 1993) [26], which states that the community promotes the cultures of the Member States, respects their national and regional diversity and, at the same time, promotes common cultural heritage. We agree with the researchers that this Treaty gave rise to the formation of the official unified cultural policy of the EU as a factor of socio-economic integration $[9,15]$.

The so-called "The Lund Principles" (2001) [25], adopted to develop coordination mechanisms among national digitization programs, are of paramount importance. These principles refer to both problems that significantly impede digitization and negatively affect integration, and ways to overcome them, both on part of Member States and the European Commission.

Slowly a need arose for more involvement of the EU countries in digitization and greater consistency between them. That is why in 2011 the European Commission substantially supplemented the "Commission Recommendation on the Digitisation and Online Access of Cultural Material and Digital Preservation" (2006) [3] and issued new "Recommendations" ("Commission recommendation of 27 October 2011 on the digitisation and online accessibility of cultural material and digital preservation" (2011/711/EU) [4]. These "Recommendations" place a premium on 5 aspects:

- Digitization: organization and funding, stating the need to develop sound plans for digitizing cultural materials, involving public-private partners, using structural funds and pooling resources to achieve cost savings;

- Digitization and online accessibility of public domain material to improve access to these digitized content;

- Digitization and online accessibility of in-copyright material reveals actions that will lead to improvements in the digitization and accessibility of copyrighted material, as well as the need to implement the provisions of the Orphan Works Directive;

- $\quad$ Europeana, aimed at encouraging cultural institutions, publishers and other right holders to make their digitized materials available through Europeana;

- Digital preservation; calls on Member States to strengthen national strategies for the long-term preservation of digital material and to adapt their legislation to the long-term preservation of digital material.

Every 2 years, Member States publish progress reports on the implementation of the "Recommendations" (2011) serving the basis for a EU consolidated report. For example, one of the last published is "Cultural Heritage: Digitization, Online Accessibility and Digital Preservation: Consolidated Progress Report on the Implementation of Commission Recommendation" (2011/711/EU) 2015-2017 [6]. The Report is built on the same principle as the Recommendations (2011), i.e. the information is presented in 5 sections: Digitization: organization and financing; digitization and online accessibility of public domain material; digitization and online accessibility of in-copyright material; Europeana; digital preservation. The report provides information on the organization and implementation of digitization, which touches on many aspects of the organizational, legal, technological nature, etc., as well as statistics, examples of best practices of Member States.

In order to improve coordination and coherence in digitization, the European Commission setting up the Expert Group on Digital Cultural Heritage and Europeana in 2017 [2]. The Expert Group was assigned with: reviewing digital cultural heritage policies, creating a forum for cooperation between Member States' authorities and the Commission, and sharing best practices on digitization and accessibility of cultural materials; promoting the development and stability of Europeana, etc.

Thus, the above analysis proves that EU culture is recognized as one of the main factors in the economic and social prosperity of the Union, and its preservation receives considerable attention of EU leadership, which pursues a coherent policy and promotes greater involvement of Member States in the digitization of historical and cultural heritage.

After examining the documents, analyzing the "Consolidated report" (2015-2017) [6] and examining the experience of the EU Member States, a number of proposals can be made to facilitate digitization in Ukraine and cultural integration with the EU. The main task facing Ukraine today is the urgent need for a significant rethinking of the role and elevation of the place of culture in the successful development of our country. An important priority for Ukraine remains the integration into the European information and cultural space and the presentation of own documentary heritage in Europeana. According to the data (August 2018) cited in the "Consolidated report" (20152017) [6], Ukraine's contribution was 1,716 objects (image 
- 1,614; text - 102; video - 0; sound - 0; 3D - 0). At the beginning of 2020, analyzing the data presented on Europeana collections [8], Ukraine's contribution remained unchanged. Unfortunately, this demonstrates the extremely unsatisfactory state of integration of Ukraine in the field of digital cultural heritage. Among the problems that significantly impede these activities and adversely affect the image of Ukraine are the lack of developed national standards, considering EU standards; low level of coordination between social institutions and public authorities; lack of proper state funding, lack of qualified staff, etc.

Therefore, the priority tasks for Ukraine in need of immediate solution can be the development and implementation of a national strategy for digitization of the historical and cultural heritage, creation of an appropriate coordinating organization, adjustment of the financing system. Let's consider these tasks in more detail.

Development and implementation of a national historical and cultural heritage digitization strategy.

The "Consolidated report" (2015-2017) [6] indicates that the vast majority of Member States have their National Digitization Strategies (19 out of 28 (at that time, the UK was still part of the EU), most of which operate under the major coordination of the relevant ministry or ministries, and national funding programs (17 out of 28). It is noteworthy that some countries implement the national strategy on digitization of cultural heritage under national digital programs, for example, in Lithuania, digitalization is part of the Digital Agenda for the Republic of Lithuania. The main areas of development of virtual space for cultural heritage are identified in the Programme of Digital Cultural Heritage Actualisation and Preservation 2015-2020 [6].

Ukraine lacks such digitalization strategy but has some obvious the legislative preconditions for its development. It is well known that the European integration activities in general were intensified after the signing of the "Association Agreement between Ukraine, of the one part, and the European Union, the European Atomic Energy Community and their Member States, of the other part" (2014) [1], in which a separate chapter (Chapter 24 "Culture") states that the Parties undertake to promote cooperation in the field of culture to improve mutual understanding and expand cultural exchanges, as well as the mobility of objects of art and artists of Ukraine and the EU, and encourage intercultural dialogue. Analyzing the analytical reports "Integration within the Association: Dynamics of the EUUkraine Agreement Implementation" for 2019 [10, 11, 12], we can conclude that the reports lack information on cultural cooperation, including in digitization of cultural heritage. We can state that among all the issues of integration of Ukraine and the EU, Ukraine does not pay enough attention to cultural integration.

In recent years, Ukraine has adopted a number of documents that can be used as a basis for developing a national digitization strategy. Among these are the Decree of the Cabinet of Ministers of Ukraine "On Approving the Strategy for the Development of the Information Society in Ukraine" (2013) [19], where, among all the diversity of areas of public life that need development, special focus is on E-culture. The main priorities of the activity are the creation of electronic versions of cultural heritage of libraries, museums, archives, fine arts (painting, graphics, sculp- ture), immovable cultural heritage (architecture, landscape), cinema, television, etc.; the Decree of the Cabinet of Ministers of Ukraine "On Approval of the Long-term Strategy for the Development of Ukrainian Culture - Reform Strategy" (2016) [18], one of the goals of which is to preserve the invaluable cultural and spiritual heritage; the Strategy also defines the main directions of activity, which should bring the sphere of culture and creativity from the periphery of socio-political interests, ensuring it a leading place in the socio-economic development of Ukraine; The Decree of the Cabinet of Ministers of Ukraine "On Approval of the Library Development Strategy until 2025 "Qualitative Changes in Libraries for Sustainable Development of Ukraine" (2016) [17], where the strategic directions of library business development include preservation of the Ukrainian cultural heritage in the part of documentary resources; its implementation implies the preservation of monuments of national and world importance in library funds as an integral part of the world cultural heritage.

Analyzing the legal acts, we can note the main drawback - their provisions are inconsistent, scattered over a large number of documents. However, in general, there is a positive trend towards culture in Ukraine. Therefore, it is important to develop a national strategy for digitizing the historical and cultural heritage that would coordinate at the national level a number of issues of organizational, technological, legal and financial nature.

Establishment of an appropriate coordinating organization.

It is also appropriate to first cite the experience of the EU Member States, setting up specialized interagency working groups of national agencies and the relevant ministry to advise and establish a national digitization strategy. For example, the Netherlands develop a national digitization strategy implemented by the Ministry of Education, Culture and Science and the Digital Heritage Network, which consists of 5 national institutions (The National Library; The Netherlands Institute for Sound and Vision; The Netherlands Cultural Heritage Agency; The Humanitarian Cluster of the Royal Netherlands Academy of Arts and Sciences; and The National Archives) [6].

In Ukraine, the most justified is the creation of an interagency group of the Ministry of Culture, Youth, and Sports of Ukraine and the Ministry of Digital Transformation of Ukraine. The Ministry of Culture, Youth, and Sports of Ukraine [24] is recognized as the main organization in the system of central executive authorities, which ensures the formation and implementation of state policy in protection of cultural heritage and preservation of monuments of national importance.

The newly created Ministry of Digital Transformation of Ukraine is assigned with the following tasks in digitization, digital development, and digital innovation. The Ministry also coordinates the activities of the executive authorities related to cooperation with the EU's Digital Single Market program and other international digital cooperation programs [21]. However, after examining the "Work Plan of the Ministry of Digital Transformation of Ukraine for 2020 " [16], we note the absence of any measures regarding digitization of cultural heritage. In our opinion, the Ministry of Digital Transformation of Ukraine should extend its powers to digitize the cultural sphere and prioritize the digitization of cultural heritage. 
The development of a national strategy also requires involvement of experts from libraries, archives, museums, document experts, IT-specialists, etc.

Therefore, coordination of concerted efforts and sharing of responsibilities between departments, social institutions and other organizations is a key to successful implementation of the digitalization strategy for cultural heritage.

Financing system.

In the near future, the main financing sources for digitization in Ukraine can be expenditures of the state budget, which should be substantially increased, and grant programs.

The level of public funding for the Ukrainian cultural sector has always been low. As S. P. Kuchyn notes, “... in 2016 the state declared its shift away from the "residual" principle of financing the sphere of culture, starting in 2017 " [14, p. 178]. Of course, there were no major changes in this direction in the following years, but only gradual increases in the state budget expenditures on culture.

Grant funding is another source of funding for digitization projects in Ukraine. Participation in grant programs, though not widespread among Ukrainian libraries, is not new. The Ukrainian Cultural Foundation [27], an institution providing competitive state promotion and multi-vector support for initiatives in the cultural and creative industries, operates in Ukraine. For example, with the support of the Ukrainian Cultural Foundation, which provides grant programs, the following projects have been implemented: "Electronic archive of periodicals "Back2News" (Central Scientific Library of V. N. Karazin Kharkiv National University, 2018); "An Electronic collection of the first third of the twentieth century Kharkiv literary and art magazines" (V. G. Korolenko Kharkiv State Scientific Library, 2019).

The attraction of EU grant programs is promising for Ukraine in financing the digitization of historical and cultural heritage. For example, there is a Creative Europe grant program [5] in the EU that supports cultural and media projects. Therefore, cooperation with the EU provides
Ukrainian libraries with new opportunities to raise additional funds for the implementation of digitization projects of historical and cultural heritage through participation in EU grant programs to receive financial support.

Conclusion. Ukraine's European integration trend requires a major rethink of the cultural heritage management system and the introduction of appropriate modernization changes to cultural policy. Cultural heritage should be a catalyst for the successful development of Ukraine as a self-sufficient country in cultural, spiritual, and socio-economic terms. Digitizing the historical and cultural heritage and forming digital collections is one of the areas of successful implementation of cultural integration with the EU. Having examined the experience of the European Union and the Member States on digitization and integration of resources, we can note that in order to achieve such high digitalization results, it is necessary to establish coordination between public authorities, social institutions, private organizations, and the public; improve and regulate national legislation and implementation of provisions of EU regulatory documents; ensure sustainable funding at the proper level; develop and implement uniform presentation formats, save digital copies, metadata, considering the formats used in Europe to facilitate further integration; and form a modern system of training of qualified specialists. This requires Ukraine to provide the following measures: development and implementation of a national strategy for digitizing the historical and cultural heritage, which should cover the integration of Ukraine and the EU in the cultural space; and establishment of an appropriate coordinating organization and a sustainable financing system.

Further research prospects. The experience of the European Union and its Member States in digitizing and providing online access to so-called "orphan works" and documents covered by copyright law must be examined. Also, the technical and technological aspects of the formation of integration resources of the historical and cultural heritage, including participation in Europeana, which is considered by Ukraine as a strategic partnership, must be studied.

\section{REFERENCES}

1. Association Agreement between Ukraine, of the one part, and the European Union, the European Atomic Energy Community and their Member States, of the other part. 2014. URL: https://zakon.rada.gov.ua/laws/show/984_011 (Last accessed: 15.12.2019).

2. Commission Decision of 7.3.2017 setting up the Expert Group on Digital Cultural Heritage and Europeana. URL: https://ec.europa.eu/information_society/newsroom/image/document/2017-42/commission_decision_dche_D19B28A2-BCEE-B2D681F1AA9FB3CE377C_47767.pdf (Last accessed: 09.12.2019)

3. Commission Recommendation of 24 August 2006 on the digitisation and online accessibility of cultural material and digital preservation (2006/585/EC) // Official Journal of the European Union. L 236, 31 August 2006. P. 28-30. URL: https://eurlex.europa.eu/legal-content/EN/TXT/PDF/?uri=CELEX:32006H0585\&from=EN (Last accessed: 08.12.2019).

4. Commission recommendation of 27 October 2011 on the digitisation and online accessibility of cultural material and digital preservation (2011/711/EU) // Official Journal of the European Union. L 283, 29 October 2011. P. 39-45. URL: https://eurlex.europa.eu/legal-content/EN/TXT/PDF/?uri=CELEX:32011H0711\&from=EN

(Last accessed: 08.12.2019).

5. Creative Europe in Ukraine : site. URL: https://creativeeurope.in.ua/ (Last accessed: 10.01.2020).

6. Cultural Heritage: Digitisation, Online Accessibility and Digital Preservation: Implementation of Commission Recommendation on the Digitisation and Online Accessibility of Cultural Material and Digital Preservation. Consolidated Progress Report 2015-2017. Working document. 2019. 69 p. URL: https://www.digitalmeetsculture.net/wp-content/uploads/2019/06/ReportonCulturalHeritageDigitisationOnlineAccessibilityandDigitalPreservation.pdf (Last accessed: 10.12.2019).

7. Dobrovolska V. V. Current changes in Ukrainian cultural policy and the development of the information and communication space of culture and documentation management // Bibliotekoznavstvo. Dokumentoznavstvo. Informolohiia. 2017. No. 2. P. 74-80.

8. Europeana collections : site. URL: https://www.europeana.eu/portal/en (Last accessed: 08.01.2020).

9. Hanskyi V. O., Andriichyk K. V. Integration actions and development programs of the European Union in historical and cultural heritage // Prychornomorski ekonomichni studii. 2018. Is. 31 .

P. 6-12. URL: http://nbuv.gov.ua/UJRN/bses_2018_31_3 (Last accessed: 16.11.2019) 
10. Integration within the Association: Dynamics of the EUUkraine Agreement Implementation: analytical report (January). Kyiv, 2019. 50 p. URL: https://www.civic-synergy.org.ua/wp-content/uploads/2018/04/Integratsiya-uramkah-asotsiatsiyi-dynamika-vykonannya-Ugody-mizhUkrayinoyu-i-YES_ua.pdf (Last accessed: 15.12.2019).

11. Integration within the Association: Dynamics of the EUUkraine Agreement Implementation: analytical report (June). Kyiv, 2019.50 p. URL: https://www.civic-synergy.org.ua/wpcontent/uploads/2018/04/Integratsiya-u-ramkah-asotsiatsiyi_dynamika-vykonannya-Ugody-mizh-Ukrayinoyu-iYES.pdf (Last accessed: 15.12.2019).

12. Integration within the Association: Dynamics of the EUUkraine Agreement Implementation: analytical report (December). Kyiv, 2019. 74 p. URL: https://www.civic-synergy.org.ua/wp-content/uploads/2018/04/Integratsiya-uramkah-asotsiatsiyi-dynamika-vykonannya-Ugody-mizhUkrayinoyu-i-YES-3-e-vydannya-1.pdf (Last accessed: 15.12.2019).

13. Kostyria I. O. Cultural policy of Ukraine in European integration // Hileia : naukovyi visnyk. 2018. Is. 131. P. 384-387. URL: http://nbuv.gov.ua/UJRN/gileya_2018_131_102 (Last accessed: 01.12.2019).

14. Kuchyn S. P. Modern directions of state cultural policy in Ukraine // Universytetski naukovi zapysky. 2017. No. 2 (62). P. 175-182.

URL: http://nbuv.gov.ua/UJRN/Unzap_2017_2_19 (Last accessed: 01.12.2019).

15. Melnychuk O. I. Legal principles of cultural heritage protection in the European Union // Naukovyi visnyk Akademii munitsypalnoho upravlinnia. Seriia: Pravo. 2011. Is. 1. P. 264 271. URL: http://nbuv.gov.ua/UJRN/Nvamu_pr_2011_1_34 (Last accessed: 16.11.2019).

16. Ministry of Digital Transformation of Ukraine : site. URL: https://thedigital.gov.ua/ (Last accessed: 10.01.2020).

17. On Approval of the Library Development Strategy until 2025 "Qualitative Changes in Libraries for Sustainable Development of Ukraine" : Decree of the Cabinet of Ministers of Ukraine No. 219-p of March 23, 2016. URL: https://zakon.rada.gov.ua/laws/show/219-2016-\%D1\%80 (Last accessed: 14.12.2019).

18. On Approval of the Long-term Strategy for the Development of Ukrainian Culture - Reform Strategy : Decree of the Cabinet of Ministers of Ukraine No. 119-p of February 01, 2016.
URL: $\quad$ https://zakon.rada.gov.ua/laws/show/119-2016$\%$ D1\%80 (Last accessed: 14.12.2019).

19. On Approving the Strategy for the Development of the Information Society in Ukraine : Decree of the Cabinet of Ministers of Ukraine No. 386-p of February 15, 2013. URL: https://zakon.rada.gov.ua/laws/show/386-2013-\%D1\%80 (access date: 14.12.2019).

20. Prykhodko L. F. Preservation of digital cultural heritage - an imperative of the 20 century (according to UNESCO and European Union documents) // Arkhivy Ukrainy. 2019. No. 2 (319). P. 67-92. URL: https://archives.gov.ua/Publicat/AU/AU_2_2019/6.pdf (Last accessed: 16.11.2019).

21. Questions of the Ministry of Digital Transformation : Resolution of the Cabinet of Ministers of Ukraine No. 856 of September 18, 2019. URL: https://zakon.rada.gov.ua/laws/show/8562019-\%D0\%BF (Last accessed: 16.12.2020).

22. Rybachok O. M. International Integrated Digital Resources of the Documentary Heritage of Archives, Libraries, Museums: Stages of Creation, Development Strategies (the 80s of the 20th - 10th of the 21st centuries) : Candidate's thesis : 27.00.02 "Documentation Science, Archival Science" / National Academy of Sciences of Ukraine, V. I. Vernadskyi National Library of Ukraine. Kyiv, 2018. 242 p.

23. Shevchenko M. I. Cultural policy of Ukraine in European integration: dilemmas and challenges // Mizhnarodni vidnosyny: teoretyko-praktychni aspekty. 2019. Is. 3. P. 215-224. DOI: https://doi.org/10.31866/2616-745x.3.2019.159124 (Last accessed: 01.12.2019).

24. Some issues related to the activity of the Ministry of Culture, Youth, and Sports : Resolution of the Cabinet of Ministers of Ukraine No. 885 of 16 October, 2019. URL: https://zakon.rada.gov.ua/laws/show/885-2019-\%D0\%BF (Last accessed: 16.12.2020).

25. The Lund Principles: Conclusions of Experts Meeting, Lund, Sweden, 4 April 2001. URL: https://www.iccu.sbn.it/export/sites/iccu/documenti/lund_principles-en.pdf (Last accessed: 08.12.2019).

26. Treaty on European Union. URL: https://europa.eu/europeanunion/sites/europaeu/files/docs/body/treaty_on_european_union_en.pdf (Last accessed: 08.12.2019).

27. Ukrainian Cultural Foundation : site. URL: https://ucf.in.ua/ (Last accessed: 10.01.2020). 